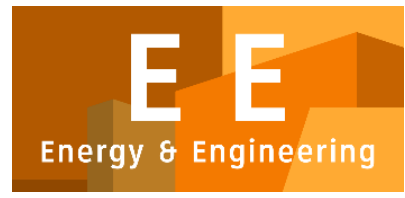

PAPER - OPEN ACCESS

\title{
Rancangan Penghitung Benih Ikan Portable Berbasis Arduino
}

\author{
Author : Jefry Yutanto \\ DOI $\quad: 10.32734 /$ ee.v1i1.115 \\ ISSN :2654-7031 \\ E-ISSN : 2654-704X
}

Volume 1 Issue 1 - 2018 TALENTA Conference Series: Energy and Engineering

\section{(cc)}

This work is licensed under a Creative Commons Attribution-NoDerivatives 4.0 International License.

Published under licence by TALENTA Publisher, Universitas Sumatera Utara
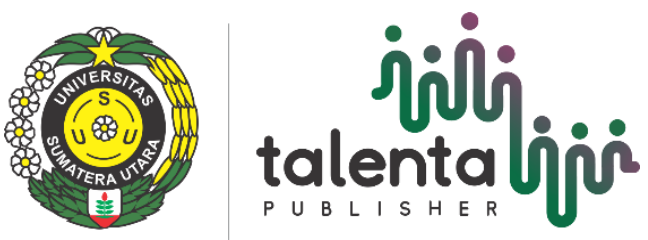
Available online at https://talentaconfseries.usu.ac.id

\title{
Rancangan Penghitung Benih Ikan Portable Berbasis Arduino
}

\author{
Jefry Yutanto ${ }^{\mathrm{a}}$, Emerson P. Sinulingga ${ }^{\mathrm{a}}$, F. Fahmi ${ }^{\mathrm{a}}$ \\ ${ }^{a}$ Fakultas Teknik, Universitas Sumatera Utara, Medan, 20155 \\ kyoshinhez@yahoo.com,fahmimn@usu.ac.id
}

\begin{abstract}
Abstrak
Pembenihan ikan merupakan usaha yang dapat dilakukan untuk membantu membudidayakan ikan, pembenihan dan penjualan benih ikan juga merupakan sektor ekonomi yang menjanjikan, namun proses penghitungan ikan masih dilakukan secara manual sehingga penghitungan membutuhkan waktu yang lama dan kurang efisien. Tulisan ini membahas mengenai prototipe alat penghitung benih ikan berbasis arduino yang dapat melakukan penghitungan lebih cepat.Alat penghitung benih ikandibuat dengan menggunakan inframerah, dioda foto, arduino UNO dan LCD 2x16. Inframerah dan dioda foto dipasang berhadapan satu sama lain pada selang. Proses penghitungan terjadi saat ada bahan yang melewati selang dan hasilnya akan ditampilkan pada layar LCD. Pengujian dilakukan dengan mimis, agar - agar, dan ikan gobi dengan menggunakan dua corong berbeda. Hasil perhitungan yang di perolehuntuk mimis dan agar - agar mencapai 100\%, dan untuk ikan gobi mencapai 96\%.
\end{abstract}

Kata Kunci: Arduino UNO; Benih ikan;

\section{Pendahuluan}

Pembenihan ikan merupakan suatu usaha yang dapat dilakukan untuk membantu membudidayakan ikan untuk setiap musim tanam.Dalam usaha budidaya ini, pembenihan memegang peran yang sangat penting.Namun keberhasilan dalam usaha pembenihan ikan bukan hanya ditentukan oleh kemampuan daya dukung lingkungan, tetapi juga oleh pengelola.

Kendala terbesar dalam usaha pembenihan ikan terdapat pada proses penghitungan jumlah ikan yang sekarang ini masih dilakukan secara manual. Perhitungan secara manual tentu saja memerlukan banyak tenaga dan waktu bahkan dapat menyebabkan ketidaktelitian pada hasil perhitungannya.Permasalahan dalam perhitungan benih ikan harus segera diatasi agar mendukung keberhasilan usaha perikanan ini sebagai bagian dari program pemerintah di bidang maritim.Diperlukan satu sistem perhitungan yang lebih cepat dan akurat agar dapat menghemat waktu perhitungan. Pada penelitian ini akan dibahas tentang perancangan sistem untuk penghitungan benih ikan portabel berbasis Arduino.

\section{Material dan Metode}

Alat penghitung benih ikan ini di buat dengan menggunakan mikrokontroller berupa arduino, inframerah, dioda foto dan layar LCD. 


\subsection{Arduino}

Arduino [1] merupakan platform prototipe elektronik yang bersifat open-source, dimana perangkat keras dan perangkat lunaknya fleksibel dan bebas untuk dimodifikasi. Arduino ditujukan bagi para seniman, desainer, dan siapapun yang tertarik dalam menciptakan objek atau lingkungan yang interaktif.

Arduino pada awalnya dikembangkan di Ivrea, Italia. Nama Arduino adalah sebuah nama maskulin yang berarti teman yang kuat. Platform arduino terdiri dari arduino board, shield, bahasa pemrograman arduino, dan arduino development environment. Arduino board biasanya memiliki sebuah chip dasar mikrokontroler Atmel AVR ATmega8 berikut turunannya. Shield adalah sebuah papan yang dapat dipasang diatas arduino board untuk menambah kemampuan dari arduino board.

Bahasa pemrograman arduino adalah bahasa pemrograman yang umum digunakan untuk membuat perangkat lunak yang ditanamkan pada arduino board. Bahasa pemrograman arduino mirip dengan bahasa pemrograman $\mathrm{C}++$.

Arduino UNO yang digunakan adalah arduino board yang menggunakan mikrokontroler ATmega328. Arduino UNO memiliki 14 pin digital (6 pin dapat digunakan sebagai output PWM), 6 input analog, sebuah $16 \mathrm{MHz}$ osilator kristal, sebuah koneksi USB, sebuah konektor sumber tegangan, sebuah header ICSP, dan sebuah tombol reset.Gambar 1 merupakan tampilan dari Arduino UNO.

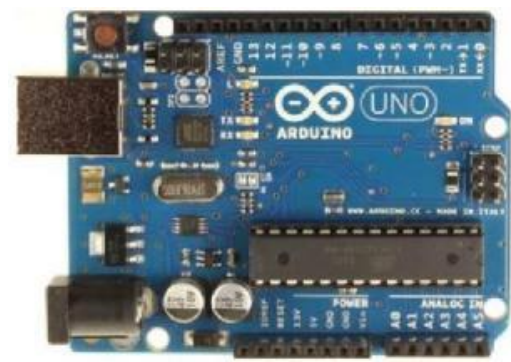

Gambar. 1. Arduino UNO

Arduino UNO memuat segala hal yang dibutuhkan untuk mendukung sebuah mikrokontroler. Hanya dengan menghubungkannya ke sebuah komputer melalui USB atau memberikan tegangan DC dari baterai atau adaptor AC ke DC sudah dapat membuanya bekerja. Arduino UNO menggunakan ATmega16U2 yang diprogram sebagai USBto-serial converter untuk komunikasi serial ke computer melalui port USB.

\subsection{Led Inframerah}

LED inframerah [3] merupakan salah satu jenis LED (Light Emiting Diode) yang dapat memancarkan cahaya inframerah yang tidak kasat mata. LED infra merah dpat memacarkan cahaya inframerah pada saat dioda LED ini diberikan tegangan bias maju pada anoda dan katodanya.Secara teoritis LED inframerah mempuyai panjang gelombang $7800 \AA$ dan mempuyai daerah frekuensi 3.104 sampai 4.104 Hz. Dilihat dari jangkah frekuensi yang begitu lebar, inframerah sangat fleksibel dalam pengunaanya. LED ini akan menyerap arus yang lebih besar dari pada dioda biasa. Semakin besar arus yang mengalir maka semakin besar daya pancarnya dan semakin jauh jaraknya.

Cahaya infra-merah tidak mudah terkontaminasi atau teresonan dengan cahaya lain, sehingga dapat digunakan baik siang maupun malam. Aplikasi dari LED infra merah ini dapat digunakan sebagai transmitter remote control maupun sebagai line detektor pada pintu gerbang. Sebagai receiver cahaya infra merah dapat digunakan dioda foto.

\subsection{Dioda Foto}

Dioda foto adalah jenis dioda yang berfungsi mendeteksi cahaya. Berbeda dengan dioda biasa, komponen elektronika ini akan mengubah cahaya menjadi arus listrik. Cahaya yang dapat dideteksi oleh diode foto ini mulai dari cahaya infra merah, cahaya tampak, ultra ungu sampai dengan sinar-X. Aplikasi dioda foto mulai dari penghitung kendaraan di jalan umum secara otomatis, pengukur cahaya pada kamera serta beberapa peralatan di bidang medis.Selain itu dioda foto merupakan suatu jenis dioda yang resistansinya berubah - ubah bila cahaya yang 
diterima pada dioda berubah - ubah intensitasnya. Dalam gelap nilai tahanannya sangat besar sehingga tidak ada arus yang mengalir, semakin kuat cahaya yang diterima dioda maka makin kecil nilai tahanannya sehingga arus yang mengalir semakin besar.Dioda foto digunakan sebagai komponen pendeteksi ada tidaknya cahaya maupun dapat digunakan untuk membentuk sebuah alat ukur akurat yang dapat mendeteksi intensitas cahaya dibawah $1 \mathrm{pW} / \mathrm{cm} 2$ sampai intensitas diatas $10 \mathrm{~mW} / \mathrm{cm} 2$. Dioda foto mempunyai resistansi yang rendah pada kondisi forward bias, kita dapat memanfaatkan dioda foto ini pada kondisi reverse bias dimana resistansi dari dioda foto akan turun seiring dengan intensitas cahaya yang masuk. Komponen ini mempunyai sensitivitas yang lebih baik jika dibandingkan dengan dioda peka cahaya.

Jika dioda foto tidak terkena cahaya, maka tidak ada arus yang mengalir ke rangkaian pembanding, jika dioda foto terkena cahaya maka dioda foto akan bersifat sebagai tegangan, sehingga Vcc dan dioda foto tersusun seri, akibatnya terdapat arus yang mengalir ke rangkaian pembanding.

\section{4. $L C D 2 \times 16$}

Liquid Crystal Display (LCD) [4] adalah suatu jenis media tampilan yang menggunakan kristal cair sebagai penampil utama. Gambar 2 merupakan tampilan dari LCD.

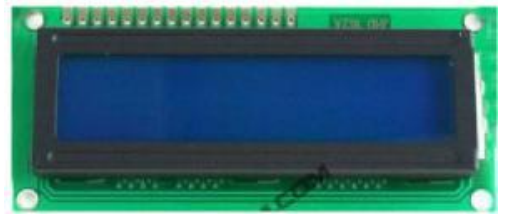

Gambar. 2. LCD 2x16

LCD sudah digunakan di berbagai bidang, misalnya dalam alat - alat elektronik seperti televisi, kalkulator ataupun layar komputer. LCD yang digunakan merupakan LCD 2x16 yang artinya LCD tersebut terdiri dari 2 baris dan 16 kolom karakter

\subsection{Alur Penelitian}

Proses percobaan sistem penghitung benih ikan dimulai dari perancangan alat, pembuatan program, pembuatan skema, percobaan dan menganalisa hasil percobaan. Untuk mengetahui seberapa besar tingkat ketelitian dari prototipe alat, alat di ujicoba dengan menggunakan mimis, agar - agar, dan bibit ikan. Gambar 3 merupakan tampilan dari alat.

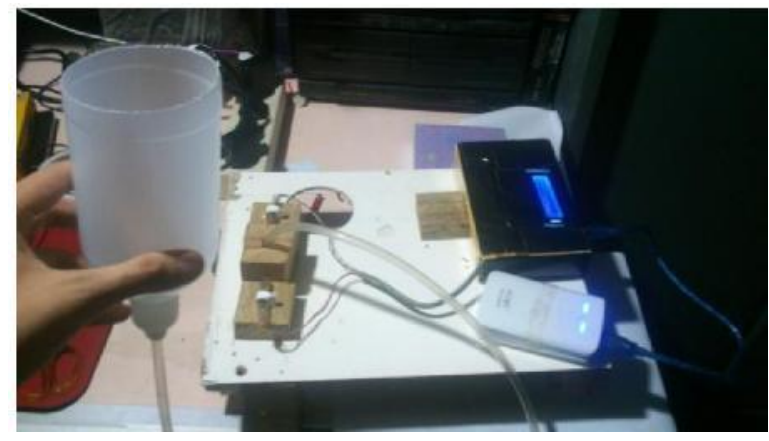

Gambar. 3. Prototipe Alat

Pemakaian alat dilakukan dengan menyambungkan selang air yang akan dilewatkan dengan bahan yang akan dihitung ke dalam sebuah kotak kecili yang sudah disediakan secara khusus. Sensor inframerah dan sensor penerima diletakkan saling berhadapan di dalam kotak kecil yang telah dibuat khusus. Alat kemudian disambungkan dengan catu daya berupa powerbank agar menyala, program dari mikrokontroller dengan sendirinya akan menyalakan fungsi sensor inframerah dan dioda foto sebagai sensor penerima. Proses penghitungan terjadi saat sensor penerima 
menerima sinar inframerah, jadi alat akan menghitung bila sensor penerima menerima sinar inframerah kembali setelah sebelumnya tertutupi oleh bahan yang lewat antara kedua sensor.

Sensitivitas merupakan nilai yang didapat dari hasil konversi tegangan keluaran dioda foto yang kita gunakan sebagai pembatas untuk menentukan apakah bahan yang lewat akan terhitung atau tidak. Rangkaian pemancar terdiri dari resistor sebagai pembatas arus serta LED inframerah sebagai piranti yang memancarkan cahaya. Sedangkan rangkaian penerima terdiri dari resistor sebagai pull-up tegangan dan dioda foto sebagai piranti yang akan menerima cahaya LED objek. Rangkaian komparator akan membandingkan tegangan input dari sensor dengan tegangan referensi untuk menghasilkan logika '0' dan '1' untuk menentukan apakah akan menghitung ataupun tidak.

LED akan memancarkan cahaya ke dioda foto dan bahan akan melewati cahaya tersebut. Intensitas cahaya yang diterima oleh dioda foto akan mempengaruhi nilai resistansinya. Semakin besar intensitas cahaya yang diterima oleh dioda foto, maka nilai resistansinya akan semakin kecil dan nilai tegangan outputnya akan semakin kecil pula. Perbedaan nilai tegangan output dari dioda foto saat menerima cahaya dari LED inframerah akan dideteksi oleh rangkaian. Tegangan referensi (sensitivitas) dapat diatur dengan memberikan nilai yang berbeda pada nilai sensitivitas pada saat penulisan program.

\section{Hasil}

Pengujian terhadap keseluruhan sistem ini merupakan pengujian akhir terhadap sistem.Pengujian alat dilakukan dengan melakukan proses penghitungan benih ikan dengan 3 bahan berbeda yaitu mimis, agar - agar dan ikan gobi. Pengujian dilakukan dengan mengguankan dua buah corong berbeda.Gambar 4 merupakan tampilan dari corong yang dipakai.
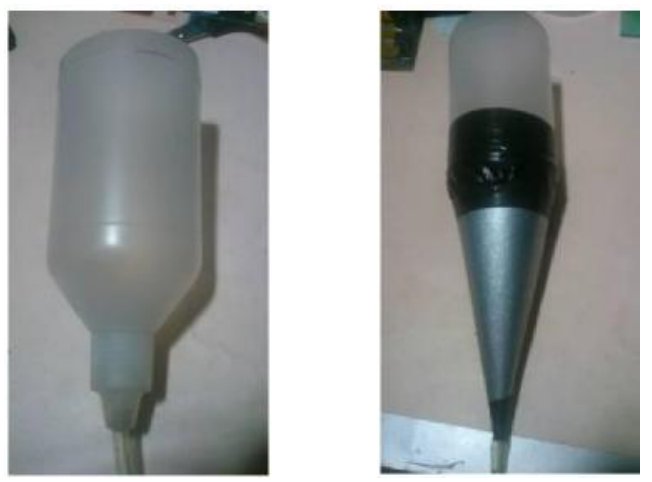

Gambar. 4. Corong Percobaan

Hasil pengujian dengan mimis (M), agar - agar (A),corong A dan nilai sensitivitas 17 dan 20 ditampilkan pada Tabel 1.Dari data pada tabel, tidak terdapat error penghitungan pada mimis dan \%error penghitungan agar - agar sebesar $0,66 \%$ (sens 17 ). Untuk sensitivitas 20 , \%error penghitungan mimis $0,66 \%$ dan \%error penghitungan agar agar mencapai 33,33\%.

Tabel. 1. Penguji.

\begin{tabular}{ccccccc}
\hline \multirow{2}{*}{ Sensitivitas } & \multicolumn{2}{c}{ Bahan } & \multicolumn{2}{c}{ Terhitung } & \multicolumn{2}{c}{$\%$ Error } \\
\cline { 2 - 7 } & M & A & M & A & M & A \\
\hline 17 & 15 & 15 & 15 & 15 & - & - \\
17 & 15 & 15 & 15 & 14 & - & $0,66 \%$ \\
17 & 15 & 15 & 15 & 15 & - & - \\
17 & 15 & 15 & 15 & 15 & - & - \\
17 & 15 & 15 & 15 & 14 & - & $0,66 \%$ \\
20 & 15 & 15 & 14 & 12 & $0,66 \%$ & $20 \%$ \\
20 & 15 & 15 & 15 & 11 & - & $26,67 \%$ \\
20 & 15 & 15 & 15 & 10 & - & $33,33 \%$
\end{tabular}




\begin{tabular}{llllccc}
20 & 15 & 15 & 14 & 12 & $0,66 \%$ & $20 \%$ \\
20 & 15 & 15 & 15 & 9 & - & $40 \%$ \\
\hline
\end{tabular}

Hasil pengujian dengan ikan gobi (G), corong A dan nilai sensitivitas 17 dan 20 ditampilkan pada Tabel 2, \% error penghitungan ikan gobi mencapai $64 \%$.

Tabel. 2. Pengujian Ikan G.

\begin{tabular}{cccc}
\hline \multirow{2}{*}{ Sensitivitas } & Bahan & Terhitung & $\begin{array}{c}\% \\
\text { Error }\end{array}$ \\
\cline { 2 - 3 } & $\mathrm{G}$ & $\mathrm{G}$ & \\
\hline 17 & 25 & 22 & $12 \%$ \\
17 & 25 & 22 & $12 \%$ \\
17 & 25 & 23 & $8 \%$ \\
17 & 25 & 24 & $4 \%$ \\
17 & 25 & 23 & $8 \%$ \\
17 & 50 & 45 & $10 \%$ \\
17 & 50 & 46 & $8 \%$ \\
17 & 50 & 44 & $12 \%$ \\
17 & 50 & 44 & $12 \%$ \\
17 & 50 & 43 & $14 \%$ \\
20 & 25 & 13 & $48 \%$ \\
20 & 25 & 10 & $60 \%$ \\
20 & 25 & 11 & $56 \%$ \\
20 & 25 & 9 & $64 \%$ \\
20 & 25 & 11 & $56 \%$ \\
20 & 50 & 25 & $50 \%$ \\
20 & 50 & 24 & $52 \%$ \\
20 & 50 & 24 & $52 \%$ \\
20 & 50 & 23 & $54 \%$ \\
20 & 50 & 22 & $56 \%$ \\
\hline
\end{tabular}

Hasil pengujian dengan ikan gobi (G), corong A dan nilai sensitivitas 17 ditampilkan pada Tabel 3.Dari data, tidak terdapat error penghitungan pada mimis dan \%error penghitungan pada agar - agar sebesar 0,66\%. Untuk sensitivitas 20, \%error penghitungan mimis $0,66 \%$ dan \%error penghitungan agar - agar mencapai 33,33\%.

Tabel. 3. Pengujian

\begin{tabular}{ccccccc}
\hline \multirow{2}{*}{ Sensitivitas } & \multicolumn{2}{c}{ Bahan } & \multicolumn{2}{c}{ Terhitung } & \multicolumn{2}{c}{$\%$ Error } \\
\cline { 2 - 7 } & M & A & M & A & M & A \\
\hline 17 & 15 & 15 & 15 & 15 & - & - \\
17 & 15 & 15 & 15 & 15 & - & - \\
17 & 15 & 15 & 15 & 15 & - & - \\
17 & 15 & 15 & 15 & 14 & - & $0,66 \%$ \\
17 & 15 & 15 & 15 & 15 & - & - \\
20 & 15 & 15 & 15 & 10 & - & $33,33 \%$ \\
20 & 15 & 15 & 15 & 11 & - & $26,67 \%$ \\
20 & 15 & 15 & 15 & 11 & - & $26,67 \%$ \\
20 & 15 & 15 & 14 & 10 & $0,66 \%$ & $33,33 \%$ \\
20 & 15 & 15 & 15 & 10 & - & $33,33 \%$ \\
\hline
\end{tabular}


Hasil pengujian dengan ikan gobi $(\mathrm{G})$, corong B dan nilai sensitivitas 20 ditampilkan pada Tabel 4, \%error penghitungan ikan gobi mencapai $14 \%$.

Tabel. 4. Pengujian Ikan

\begin{tabular}{|c|c|c|c|}
\hline \multirow{2}{*}{ Sensitivitas } & Bahan & Terhitung & \multirow{2}{*}{$\begin{array}{c}\% \\
\text { Error }\end{array}$} \\
\hline & $\bar{G}$ & G & \\
\hline 17 & 25 & 24 & $4 \%$ \\
\hline 17 & 25 & 25 & - \\
\hline 17 & 25 & 22 & $12 \%$ \\
\hline 17 & 25 & 23 & $8 \%$ \\
\hline 17 & 25 & 23 & $8 \%$ \\
\hline 17 & 50 & 43 & $14 \%$ \\
\hline 17 & 50 & 48 & $4 \%$ \\
\hline 17 & 50 & 45 & $10 \%$ \\
\hline 17 & 50 & 45 & $10 \%$ \\
\hline 17 & 50 & 44 & $12 \%$ \\
\hline 20 & 25 & 11 & $56 \%$ \\
\hline 20 & 25 & 12 & $52 \%$ \\
\hline 20 & 25 & 8 & $68 \%$ \\
\hline 20 & 25 & 10 & $40 \%$ \\
\hline 20 & 25 & 12 & $52 \%$ \\
\hline 20 & 50 & 23 & $54 \%$ \\
\hline 20 & 50 & 21 & $58 \%$ \\
\hline 20 & 50 & 22 & $56 \%$ \\
\hline 20 & 50 & 24 & $52 \%$ \\
\hline 20 & 50 & 22 & $56 \%$ \\
\hline
\end{tabular}

\section{Pembahasan}

Pembahasan hasil pengujian akan dilakukan dengan melihat beberapa parameter sensitivitas yang berbeda

\subsection{Nilai Sensitivitas 20}

Sensitivitas merupakan suatu variabel dari sensor penerima.Sensitivitas menandakan seberapa besar sinar inframerah yang diterima agar termasuk dalam kategori "terdapat bahan yang lewat". Sensitivitas juga menentukan besar dan kecil dari bahan yang akan dilewatkan, bila niilai sensitvitas semakin kecil, sensor akan semakin peka, sehingga bahan yang kecil juga dapat dihitung. Namun bila nilai sensitivitas besar, bahan yang kecil tidak dapat terhitung, alat hanya dapat menghitung bahan yang besar.

Dari hasil pengujian dengan menggunakan nilai sensitivitas 20 dapat dilihat bahwa percobaan dengan bahan mimis cukup akurat dergan nilai error tertinggi hanya $0,66 \%$, hal ini dikarenakan mimis memiliki tekstur yang padat dan solid. Pada percobaan dengan bahan agar - agar hasil yang didapat kurang akurat dengan error tertinggi mencapai $40 \%$, hal ini dikarenakan nilai sensitivitas 20 masih kurang sensitif untuk menghitung agar - agar yang memiliki tekstur kurang padat sehingga sensor tidak dapat melakukan penghitungan dengan baik. Pada percobaan dengan bahan benih ikan hasil yang didapat tidak akurat dengan nilai error tertinggi mencapai $68 \%$, hal ini dikarenakan saat percobaan, terdapat benih ikan yang tertinggal atau melompat keluar dari corong, nilai sensitivitas 20 masih kurang sensitif untuk menghitung benih ikan yang memiliki tekstur kurang padat dengan warna yang tidak terlalu pekat ( agak transparan). 
Dari hasil percobaan yang telah dilakukan, nilai sensitivitas 20 dapat menghitung bahan mimis dengan baik dan akurat, sedangkan untuk bahan agar - agar dan benih ikan, nilai sensitivitas 20 tidak dapat menghitung dengan baik dan tidak akurat.

\subsection{Nilai Sensitivitas 17}

Dari hasil pengujian dengan menggunakan nilai sensitivitas 17 dapat dilihat bahwa percobaan dengan bahan mimis sudah akurat dergan tidak adanya nilai error yang dihasilkan, hal ini dikarenakan mimis memiliki tekstur yang padat dan solid. Pada percobaan dengan bahan agar - agar hasil yang didapat cukup akurat dengan error tertinggi 0,66\%, hal ini menunjukkan bahwa nilai sensitivitas 17 sudah cukup sensitif untuk dapat menghitung agar - agar dengan baik. Pada percobaan dengan bahan benih ikan hasil yang didapat lebih akurat dengan nilai error tertinggi $14 \%$, hal ini dikarenakan saat percobaan, terdapat benih ikan yang tertinggal atau melompat keluar dari corong, nilai sensitivitas 17 sudah cukup sensitif untuk menghitung benih ikan, untuk mendapatkan hasil yang lebih baik dapat menggunakan nilai sensitivitas 16 namun harus berhati - hati karena dengan nilai sensitivitas 16 , alat menjadi lebih sensitif dan dapat mendeteksi bercak air yang tersisa pada selang yang menyebabkan perhitungan menjadi tidak akurat.

Dari hasil percobaan yang telah dilakukan, nilai sensitivitas 17 dapat menghitung bahan mimis dan agar - agar dengan baik dan akurat, Sedangkan untuk bahan benih ikan, error yang terjadi diakibatkan oleh faktor eksternal seperti benih ikan yang sangkut dan benih ikan yang melompat keluar dar corong sehingga hasil penghitungan yang terjadi menjadi kurang akurat. Nilai sensitivitas 17 sudah dapat menghitung dengan baik dan lebih akurat. Semakin kecil nilai sensitvitas maka alat juga akan menjadi semakin sensitif.

\subsection{Dua corong berbeda}

Dari hasil pengujian yang telah dilakukan, tidak terlihat adanya perbedaan penghitungan dengan bahan mimis dan agar - agar. Pada percobaan dengan bahan benih ikan terdapat sedikit perbedaan, dengan corong tipe A benih ikan cenderung tertinggal atau tersisa dalam corong dan benih ikan yang melewati selang lebih padat, sedangkan dengan corong tipe $\mathrm{B}$ benih ikan lebih jarang tertinggal atau tersisa dalam corong dan benih ikan yang melewati selang lebih teratur.

\section{Kesimpulan}

Dari hasil pembahasan, diperoleh kesimpulan sebagai berikut :

- Alat penghitung benih ikan dapat menghitung dengan kecepatan 1 detik / bahan

- Alat penghitung benih ikan dapat menghitung mimis dengan tingkat akurasi hingga $100 \%$

- Alat penghitung benih ikan dapat menghitung agar - agar dengan tingkat akurasi hingga 100\%

- Alat penghitung benih ikan dapat menghitung ikan gobi dengan akurasi hingga $96 \%$

\section{Referensi}

[1] "Wikipedia" [Online]. Available : http://en.wikipedia.org/wigi/Arduino.

[2] "Arduino" [Online]. Available : http://arduino.cc/en/Main/ArduinoBoardUno.

[3] Gunawan, Hanapi.,Malvino. 1985. "Prinsip - prinsip Elektronik‘. Jakarta : Erlangga.

[4] M.G.Simanjuntak, Perancangan Prototipe Smart Building berbasis Arduino UNO, Medan : Teknik Elektro Universitas Sumatera Utara, 2013. 